\title{
Patients with lipodystrophic diabetes mellitus of the Seip-Berardinelli type, express normal insulin receptors
}

\author{
E.R. van der Vorm ${ }^{1}$, A. Kuipers ${ }^{1}$, J.W. Bonenkamp ${ }^{2}$, W.J. Kleijer ${ }^{3}$, L. Van Maldergem ${ }^{4}$, J. Herwig ${ }^{5}$ and J. A. Maassen $^{1}$ \\ ${ }^{1}$ Department of Medical Biochemistry, Sylvius Laboratories, State University, Leiden; ${ }^{2}$ Sophia Children's Hospital, Rotterdam and \\ ${ }^{3}$ Department of Clinical Genetics, Erasmus University, Rotterdam, The Netherlands; \\ ${ }^{4}$ Institut de Morphologie Pathologique, Loverval, Belgium; ${ }^{5}$ Klinikum der JW Goethe Universität, Frankfurt am Main, FRG
}

Summary. Lipodystrophic diabetes mellitus of the Seip-Berardinelli type is a syndrome associated with insulin resistance and recessive inheritance. We have examined whether mutations in the insulin receptor are pathogenetic factors in this syndrome. Fibroblasts from three different patients with Seip-Berardinelli's lipodystrophy were tested for insulin binding, and insulin-stimulated receptor autophosphorylation. In addition, the coding region of both alleles of the insulin receptor gene was sequenced. No abnormalities in the number of high affinity insulin binding sites, and insulinstimulated receptor autophosphorylation were detected. The insulin receptor related insulin-like growth factor I receptor also showed no functional changes. DNA sequence analysis of the amplified exons of the insulin receptor gene showed a silent mutation in patient 1 at codon $\operatorname{Ser}^{339}$, changing AGT to AGC. In patient 2 a heterozygous Met for Val substitution at position 985 was detected, which is a rare polymorphism. In patient 3 no mutations, other than described polymorphisms, were observed. These findings demonstrate that the primary genetic lesion in Seip-Berardinelli's lipodystrophy is outside the insulin receptor gene and that an involvement of the insulin-like growth factor I receptor is also unlikely.

Key words: Lipodystrophic diabetes mellitus, insulin resistance, insulin receptor, IGF-I receptor, polymorphisms, SeipBerardinelli syndrome.
Insulin resistance is a characteristic of several inborn syndromes. In some of these, genetic factors contribute to the pathogenesis of the disease. Insulin resistance can originate from mutations in the insulin receptor (IR) gene or from mutations in post-receptor components which are involved in expressing insulin action.

Mutations in the genes for glucokinase [1] and mitochondrial DNA [2] are examples of post-receptor defects found in a few particular families with maturity-onset diabetes of the young and Type 2 (non-insulin-dependent) diabetes mellitus. On the other hand, a large number of mutations in the IR have been detected in patients with a variety of insulin resistance syndromes, such as leprechaunism, type A insulin resistance and the RabsonMendenhall syndrome [3]. Especially intriguing are those IR mutations which cause aberrant signalling, affecting only a subset of biological responses of insulin and leaving other responses almost normal [4].

Most cells express, in addition to the IR, also the related receptors for insulin-like growth factor I (IGF-I) which can activate similar signalling pathways as the IR and it is conceivable that these receptors may contribute to correct in vivo insulin action.
Particular characteristics of Seip-Berardinelli's lipodystrophy (SBLD) are insulin resistant diabetes, growth anomalies, acanthosis nigricans, genital hypertrophy, hepatomegaly and hirsutism, symptoms frequently seen in patients with IR mutations. An additional feature of this syndrome is that the anabolic action of insulin on fat is predominantly affected. The anabolic action on protein appears unchanged, as concluded from the muscular hypertrophy resulting in the typical "herculean" aspect of these patients. As such a situation can result from mutations in the IR causing discordant signalling, we have examined the function and structure of the IR in fibroblasts from three unrelated patients with SBLD. All the patients were born from consanguineous marriages. The fibroblasts were tested for IR mRNA expression, insulin binding and insulin-stimulated autophosphorylation of the IR. In addition, the sequence of the coding region of the IR was determined. The possible involvement of an altered IGF-I receptor function in the pathogenesis of SBLD was examined through IGF-I binding and IGF-I stimulated autophosphorylation of the IGF-I receptor. 


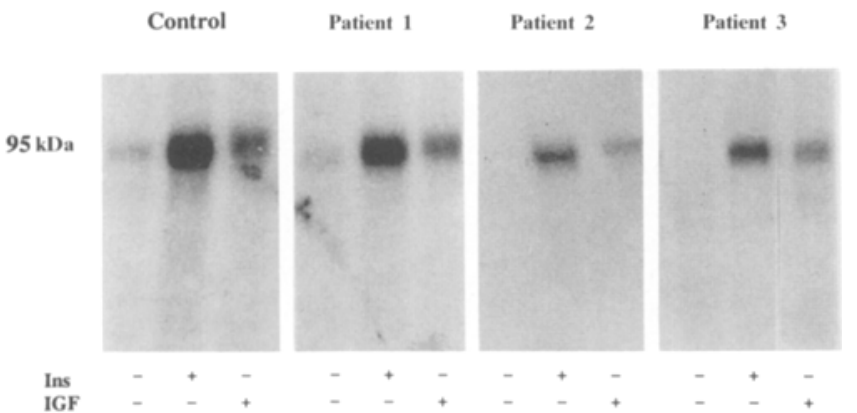

Fig.1. Autophosphorylation in fibroblasts of the three patients and a control subject. From each subject three experiments are shown: unstimulated, stimulated with insulin (Ins) and stimulated with insulin-like growth factor I (IGF). The $\beta$-chain is seen at the level of $95 \mathrm{kDa}$.

\section{Materials and methods}

\section{Materials}

Fibroblasts of three children with the clinical diagnosis of SBLD were investigated. All the patients were from consanguineous marriages and showed characteristics of SBLD such as lack of subcutaneous fat, hyperlipidaemia and hepatomegaly. Patient 1 , a Caucasian female, 15 years old, had fasting hyperinsulinaemia $(215 \mathrm{mU} / \mathrm{l})$, glucosuria and acanthosis nigricans. Patient 2, a mediterranean female, 13 years old, was overtly diabetic, also had glucosuria and received $5 \mathrm{U} \cdot \mathrm{kg}^{-1} \cdot$ day $^{-1}$ insulin i.m.. Patient 3 , a mediterranean male, 2 years old, was normoglycaemic with fasting hyperinsulinaemia (34 mU/1) and showed accelerated growth.

\section{Methods}

Conditions for fibroblast culture, mRNA isolation, Northern blot analysis, binding of insulin and IGF-I, receptor autophosphorylation and direct sequencing of amplified IR-exons have been described [5]. The codon numbering is according to Ebina et al.[6]

\section{Results}

Northern blot analysis of IR mRNA in total RNA from fibroblasts of all three patients showed a normal level of expression and no detectable change in the size of the various IR mRNAs. Also, the number of high affinity binding sites for insulin and IGF-I was not decreased. Remarkably the insulin binding in patient 2 was $0.35 \pm 0.03 \mathrm{fmol} / 10^{6} \mathrm{fi}-$ broblasts (control subjects: $0.12-0.22 \mathrm{fmol} / 10^{6}$ ). Both receptors showed a normal increase in ligand-induced autophosphorylation of the receptor $\beta$-subunits (Fig. 1).

Direct sequencing of DNA isolated from the fibroblasts demonstrated in patient 1 a silent, heterozygous mutation at $\mathrm{Ser}^{339}$, changing AGT into AGC. Patient 2 was heterozygous for the rare $\mathrm{Met}^{985}$ variant and patient 3 showed a normal IR gene sequence with only the published polymorphisms. All three patients proved to be heterozygous for polymorphisms in the IR gene (Table 1).
Table 1. Polymorphisms in the insulin receptor of three patients with Seip-Berardinelli's lipodystrophy

\begin{tabular}{|c|c|c|c|c|}
\hline \multirow{2}{*}{$\begin{array}{l}\text { Position, } \\
\text { codon }\end{array}$} & \multirow[t]{2}{*}{ Polymorphisms } & \multicolumn{3}{|c|}{ Number of alleles in: } \\
\hline & & Patient 1 & Patient 2 & Patient 3 \\
\hline \multirow[t]{2}{*}{144} & TAC, Tyr $^{\mathrm{a}}$ & 2 & 2 & 2 \\
\hline & $\mathrm{CAC}, \mathrm{His}^{\mathrm{b}}$ & - & - & - \\
\hline \multirow[t]{2}{*}{276} & $\mathrm{CAG}, \mathrm{Gln}^{\mathrm{a}}$ & 2 & 2 & 2 \\
\hline & $\mathrm{CAA}, \mathrm{Gln}^{\mathrm{b}}$ & - & - & - \\
\hline \multirow[t]{2}{*}{339} & AGT, $\operatorname{Ser}^{a, b}$ & 1 & 2 & 2 \\
\hline & $A G C$, Ser $^{d}$ & 1 & - & - \\
\hline \multirow[t]{2}{*}{421} & ATC, $\mathrm{Ile}^{\mathrm{a}}$ & 2 & - & 2 \\
\hline & ACC, Thr & - & 2 & - \\
\hline \multirow[t]{2}{*}{465} & $\mathrm{CAG}, \mathrm{G} \ln ^{\mathrm{a}}$ & 2 & - & 2 \\
\hline & AAG, Lys $^{\mathrm{b}}$ & - & 2 & - \\
\hline \multirow[t]{2}{*}{519} & $\mathrm{GAC}, \mathrm{Asp}^{a}$ & 1 & 1 & 2 \\
\hline & GAT, $\mathrm{Asp}^{\mathrm{b}}$ & 1 & 1 & - \\
\hline \multirow[t]{2}{*}{523} & GCA, $\mathrm{Ala}^{\mathrm{a}}$ & 1 & - & 1 \\
\hline & $\mathrm{GCG}, \mathrm{Ala}^{\mathrm{b}}$ & 1 & 2 & 1 \\
\hline \multirow[t]{2}{*}{873} & GAC, Asp $^{\mathrm{a}}$ & - & - & - \\
\hline & GTC, $\mathrm{Val}^{\mathrm{b}}$ & 2 & 2 & 2 \\
\hline \multirow[t]{2}{*}{874} & $\mathrm{ACC}, \mathrm{Thr}^{\mathrm{a}}$ & - & - & - \\
\hline & TCC, Ser & 2 & 2 & 2 \\
\hline \multirow[t]{2}{*}{985} & GTG, $\mathrm{Val}^{\mathrm{a}, \mathrm{b}}$ & 2 & 1 & 2 \\
\hline & $\mathrm{ATG}, \mathrm{Met}^{\mathrm{c}}$ & - & 1 & - \\
\hline \multirow[t]{2}{*}{1251} & $\mathrm{AAC}, \mathrm{Asn}^{\mathrm{a}}$ & - & - & - \\
\hline & AAG, Lys $^{\mathrm{b}}$ & 2 & 2 & 2 \\
\hline
\end{tabular}

${ }^{\mathrm{a}}$ Ullrich et al. [10], ${ }^{\mathrm{b}}$ Ebina et al. [6], ${ }^{\mathrm{c}}$ O'Rahilly et al. [9],

${ }^{\mathrm{d}}$ The new polymorphism in patient 1

\section{Discussion}

Seip-Berardinelli's lipodystrophy (SBLD) is a distinct type of lipodystrophic diabetes. There are acquired and inborn forms of lipodystrophic diabetes. Of the latter an $\mathrm{x}$-linked (Köbberling-Dunnigan syndrome) and an autosomal recessive inheritance pattern (SBLD) have been described. In SBLD a high rate of consanguinity is found, suggesting that homozygous genetic defects rather than compound heterozygous lesions may be involved.

A number of clinical features of SBLD resemble those of other syndromes with insulin resistance where a primary involvement of IR mutations in the pathogenesis of the disease has been demonstrated. Consequently, several groups have examined whether an abnormal function of the IR is involved in SBLD. Magre et al.[7] found normal insulin binding in six different patients with unspecified lipodystrophic diabetes. Despite the normal insulin binding, several alterations in glucose metabolism were shown and these authors suggested a post-binding defect in these cases. In contrast Kriauciunas et al.[8] reported three lipodystrophic patients of one family, having an impaired expression of IR mRNA, decreased insulin binding and decreased autophosphorylation. They proposed a primary involvement of the IR.

In our patients with SBLD, analysis of IR properties showed that the number of high affinity IRs was within the normal range or, in patient 2 , even elevated. Insulin induced a normal stimulation of autophosphorylation. In 
agreement with these findings, no abnormalities at the level of IR mRNA were seen.

Although no functional defects of the IR could be detected, the possibility still existed that mutations were present which did not affect insulin binding or IR autophosphorylation but rather coupling of the activated receptor with specific signalling pathways. A mutation of this kind has been described in the $\beta$-chain of the IR by Moller et al.[4] in a patient with type A insulin resistance.

To examine this possibility we sequenced the coding region of the IR gene of the three patients. In patient 1 we found a silent mutation at position 339, changing AGT into AGC. Patient 2 was heterozygous for the $\mathrm{Met}^{985} \mathrm{mu}$ tation. This mutation was initially detected in a patient with Type 2 diabetes, but a recent report by O'Rahilly et al.[9] indicated that it occurred both in diabetic and non-diabetic subjects, suggesting that it is a polymorphism. Except for these two polymorphisms, no alterations in the IR gene were seen other than the polymorphisms described by Ebina et al.[6] and Ullrich et al.[10]. Furthermore, we expected a homozygous gene defect in the patients because of consanguinity of their parents. The heterozygosity for some polymorphisms of the IR gene argues against the involvement of IR defects.

In conclusion, we found no IR defect in three patients with Seip-Berardinelli's lipodystrophy and also IGF-I receptor functions were normal. Thus, the inability of insulin to stimulate the anabolic action on fat in these patients seems to result from a post-receptor lesion. This defect can reside in enzymatic pathways for lipid metabolism or in factors regulating the growth and proliferation of adipocytes.

Acknowledgements. We thank Drs. H. M.J. Krans, D. Lindhout and W. Möller for helpful discussions. This study was supported by grants from The Netherlands Organization for the Advancement of Pure Research (NWO) through the foundation of Medical Research (GB-MW).

\section{References}

1. Vionnet N, Stoffel M, Takeda J et al. (1992) Nonsense mutation in the glucokinase gene causes early-onset non-insulin-dependent diabetes mellitus. Nature 356: 721-722

2. Van den Ouweland JWM, Lemkes HHPJ, Ruitenbeek W et al. (1992) Mutation in mitochondrial tRNA ${ }^{\text {leu }}$ (UUR) gene in a large pedigree with maternally transmitted type II diabetes mellitus and deafness. Nature Genetics 1:368-371

3. Taylor SI, Cama A, Acilli D et al. (1991) Genetic basis of endocrine disease 1. J Clin Endocrinol Metab 73: 1158-1163

4. Moller DE, Benecke H, Flier JS (1991) Biologic activities of naturally occurring human insulin receptor mutations. J Biol Chem 266: 10995-11001

5. Van der Vorm ER, Van der Zon GCM, Möller W, Krans HMJ, Lindhout D, Maassen JA (1992) An Arg for Gly substitution at position 31 in the insulin receptor, linked to insulin resistance, inhibits receptor processing and transport. J Biol Chem 267: 66-71

6. Ebina Y, Ellis L, Jarnagin $\mathrm{K}$ et al. (1985) The human insulin receptor cDNA: the structural basis for hormone activated transmembrane signalling. Cell 40: 747-758

7. Magre J, Reynet C, Capeau J, Blivet M-J, Picard J (1988) In vitro studies of insulin resistance in patients with lipoatrophic diabetes. Diabetes 37: 421-428

8. Kriauciunas KM, Kahn CR, Muller-Wieland D, Sethu S, Reddy $\mathrm{K}$, Taub R (1988) Altered expression a function of the insulin receptor in a family with lipoatrophic diabetes. J Clin Endocrinol Metab 67: 1284-1292

9. O'Rahilly S, Krook A, Rees A, Flier JS, Moller DE (1992) Insulin receptor and insulin-responsive glucose transporter (GLUT4) mutations and polymorphisms in a Welsh Type 2 (non-insulin-dependent) diabetic population. Diabetologia 35:486-489

10. Ullrich A, Bell JR, Chen EY et al. (1985) Human insulin receptor and its relationship to the tyrosine kinase family of oncogenes. Nature 313: 756-761

Received: 15 September 1992 and in revised form: 12 October 1992

Dr. E.R. van der Vorm

State University Leiden, Department of Medical Biochemistry

Sylvius Laboratories

Wassenaarseweg 72

NL-2333 AL Leiden, The Netherlands 